\title{
Mucociliary transport, differential white blood cells, and cyto-genotoxicity in peripheral erythrocytes in fish from a polluted urban pond
}

\author{
Edison Bezerra da Silva ${ }^{1,2} \cdot$ Sandra Aparecida da Silva Corrêa ${ }^{1}$. \\ Denis Moledo de Souza Abessa ${ }^{3}$ • Bruno Ferreira Xavier da Silva ${ }^{4}$. \\ Dolores Helena Rodriguez Ferreira Rivero ${ }^{4,5} \cdot$ Robson Seriani ${ }^{4,5}$
}

Received: 11 July 2017 / Accepted: 8 November 2017 / Published online: 13 November 2017

(C) Springer-Verlag GmbH Germany, part of Springer Nature 2017

\begin{abstract}
The present study evaluated the water quality of a polluted pond through the analysis of in vitro mucociliary transport, hematological parameters, and biomarkers of cytogenotoxicity in the Nile tilapia (Oreochromis niloticus). Blood and mucus samples were collected from ten specimens from the polluted pond and from ten specimens from a control area. The fish were anesthetized with $3 \%$ benzocaine, mucus was collected directly from the gills, and blood was drawn from the caudal artery. Blood smears were stained using the MayGrünwald Giemsa process for the differential leukocyte counts and to determine the frequency of leukocytes, thrombocytes, erythroblasts, micronuclei, and nuclear abnormalities. The results revealed low transportability in vitro, a high percentage of monocytes and eosinophils, and increased frequency of leukocytes and nuclear abnormalities in fish from the polluted pond. However, the frequency of thrombocytes and erythroblasts and the percentage of lymphocytes and neutrophils were significantly lower. It is possible to conclude that
\end{abstract}

Responsible editor: Diane Purchase

Robson Seriani

robsonseriani@usp.br

1 Pós-Graduacão em Ecogestão, Campus Paraíso, Universidade Paulista—UNIP, São Paulo, Brazil

2 Escola Municipal de Ensino Fundamental Olavo Fontoura, Prefeitura do Município de São Paulo, São Paulo, Brazil

3 Campus do Litoral Paulista-Núcleo de Estudos em Poluição e Ecotoxicologia Aquática, Universidade Estadual Paulista-UNESP, São Vicente, Brazil

4 Faculdade das Américas-FAM, São Paulo, Brazil

5 Departamento de Patologia, Faculdade de Medicina, Laboratório de Investigação Médica LIM05, Universidade de São Paulo, Av. Dr. Arnaldo $455,1^{\circ}$ andar, sala 1150, Cerqueira César, São Paulo, Brazil changes in fish are due to poor water quality and that these non-destructive biomarkers can be used for the biomonitoring of aquatic environments vulnerable to contamination.

Keywords Aquatic pollution · Biomarkers · Mucus · Hematology $\cdot$ Cytotoxicity $\cdot$ Oreochromis niloticus

\section{Introduction}

The growth of the world's human population and the consequently higher demands for food and manufactured products have both led to increased waste on the planet. Domestic sewage, industrial effluents, urban drainage, and agricultural leachates represent important sources of contamination in water bodies. Reduced water quality is one of the causes of water shortages worldwide; thus, modern societies have recognized the importance and preciousness of water to human health, agricultural and industrial productivity, and an ecological balance (Morris et al. 2016; Flores-Ramirez et al. 2017).

In urban areas, aquatic ecosystems are more susceptible to degradation, and many vertebrates and invertebrates have been used to monitor environmental quality. Changes in functional enzymes (Bonnail et al. 2016; Vieira et al. 2017; Sadauskas-Henrique et al. 2017), effects of cytogenotoxicity (Prado, et al. 2014, de Almeida Duarte et al. 2016), mutagenicity (Araújo al. 2014; Weldetinsae et al. 2017), and hematological, immunological, and histopathological changes (da Cruz et al., 2015; Corrêa et al. 2017; Thummabancha et al. 2016; Hedayati and Darabitabar 2017) all represent well-documented biomarkers used in environmental monitoring.

Several fish species have been frequently used to detect and assess the biological effects of contaminants released into 
water bodies, as they may exhibit lethal and sublethal responses to chemicals. These organisms are considered appropriate for use in pollution monitoring in aquatic systems because they occupy different positions within the food web and may transfer energy and biomass between trophic levels. Furthermore, the presence of pollutants in the environment can cause stress by changing molecular, physiological, histological, or behavioral responses.

In Brazilian legislation, the quality of environmental surface waters is monitored using only physicochemical and microbiological parameters (e.g., fecal coliforms), which are compared to the national limits established for the respective variables and water classes. Good-quality waters must not present variables exceeding the national guidelines for environmental contamination; however, for a proper understanding of ecological risks to fauna, specific information on bioavailability or potential toxicological effects on the biota must be gathered.

The aim of this study was to determine whether fish from a polluted artificial urban pond that receives urban effluents exhibited alterations in mucociliary transport in vitro, cytogenotoxicity in peripheral erythrocytes, and immunological responses, as measured by differential leukocyte counts and frequency of total leukocytes, thrombocytes, erythroblasts, micronuclei, and nuclear abnormalities as non-destructive biomarkers for aquatic monitoring, toxicological studies, and aquaculture.

\section{Methods}

\section{Study area}

The study area was a polluted artificial urban pond in the city of Santo André, in the state of São Paulo, Brazil (23 $37^{\prime} 53^{\prime \prime}$ $\left.\mathrm{S}, 46^{\circ} 31^{\prime} 58.73^{\prime \prime} \mathrm{W}\right)$. Previous studies had reported that the pond receives domestic effluent and storm water discharge, processes which periodically result in algal blooms and/or episodes of massive fish mortality (Seriani et al. 2012a). The water quality is poor, with high concentrations of ammonia, as well as high conductivity and hardness; the pond's volume is low and its maintenance depends exclusively on rainfall precipitation (Seriani et al. 2012b).

\section{In vitro mucociliary transport}

Mucociliary transport was measured in vitro according to the method used by Seriani et al. (2015a). This technique is an adaptation of the protocol previously described by King (1986) and Macchione et al. (1995) and Trindade et al. (2018). For the mucus sampling $(20 \mu \mathrm{L})$, the gills were carefully scraped with a brush and placed in Eppendorf® microtubes, each of which contained $1 \mathrm{~mL}$ of mineral oil to prevent dehydration and was stored at $-20^{\circ} \mathrm{C}$ until processing.

In the laboratory, the in vitro mucociliary transport rates were evaluated using an American bullfrog (Lithobates catesbeianus) palate preparation (King 1986; Macchione et al. 1995). The experiments were performed at room temperature $\left(20^{\circ} \mathrm{C}\right)$, and five measurements were recorded for each mucus sample. The results are expressed as the relative speed of mucus along the palate, which was calculated by dividing the distance traveled $(6 \mathrm{~mm})$ by the elapsed time (seconds). After measuring the elapsed time, the value of the sample was divided by that of the autologous mucus (from the frog) to establish the relative speed (sample vs. frog; Saldiva 1990; Macchione et al. 1995). It is important to note that this procedure was incorporated into other research projects conducted in our laboratory and that the mucociliary transport analysis was therefore performed only when frogs needed to be euthanized for other scientific purposes; no animals were killed solely to produce data for the present investigation.

\section{Test organisms and hematological analyses}

The experimental protocol was approved by the Research Ethics Committee of São Paulo State University (UNESP). The animals were handled according to the ethical standards of animal experimentation, and at the end of the procedures, the surviving individuals were acclimatized with the same water for recovery and reinserted into their environment.

Twenty Nile tilapia (Oreochromis niloticus) specimens were collected for this study (ten from the polluted pond and ten from a private fish farm used as a control site). The mean weight of the collected fish was $30.0 \pm 1.1 \mathrm{~g}$, and the mean length was $10.1 \pm 0.2 \mathrm{~cm}$. All specimens were placed in tanks containing water from the respective collection sites and were acclimatized for $60 \mathrm{~min}$ to minimize the stress of collection (Corrêa et al. 2017). Next, the fish were anesthetized with clove oil according to Simões et al. (2012) and to Delbon and Paiva (2012). Blood was drawn from the caudal artery, a procedure which was performed using heparin-treated syringes. Blood smears were then prepared on glass slides and stained using the May-Grünwald Giemsa process (Rosenfeld 1947; Seriani et al. 2011). Two thousand cells were analyzed per slide/animal under an optical microscope $(\times 1,000)$, and the frequencies of total leukocytes, thrombocytes, and erythroblasts were identified and counted. Additional blood smears were used for differential (percent) leukocyte counts (lymphocytes, neutrophils, basophils, monocytes, and eosinophils).

\section{Cyto-genotoxicity analysis}

Two thousand cells were analyzed per slide/animal under a microscope $(\times 1,000)$. Micronuclei, which were defined as two completely separated nuclei within a single erythrocyte's 
cytoplasm, were identified, and their frequencies were recorded. Nuclear abnormalities are understood as precursors of further DNA damage, and they include invaginations of the nuclear envelope of different sizes, noticeable depressions in the center in which nuclear material was otherwise absent, as well as other morphological abnormalities that did not fit into the previous categories (Bucker et al. 2012; Prado et al. 2014; Seriani et al. 2015b; Thomé et al. 2016).

\section{Water samples}

Surface water samples were collected using glass flasks. They were frozen and stored until the use in the physicochemical analyses, which considered the measurements recommended by the APHA (2005): conductivity $(\mu \mathrm{S} / \mathrm{cm})$, temperature $\left({ }^{\circ} \mathrm{C}\right)$, $\mathrm{pH}$, hardness $\left(\mathrm{mg} / \mathrm{CaCo}_{3}\right)$, and dissolved oxygen content $(\mathrm{mg} /$ L). Total ammonia concentrations $\left(\mathrm{NH}_{3}-\mathrm{NH}_{4}\right)$ were measured using the colorimetric method (Koroleff 1970).

\section{Statistical analysis}

Descriptive analyses for quantitative data with normal distribution are presented as means and their respective standard deviations. The distribution of data (normality) and the homogeneities of variances were confirmed using the ShapiroWilks test and the Bartlett test, respectively. The results were then compared to their respective controls using Student's $t$ test for independent samples in order to determine any significant differences. The level of significance was set to 5\%, and statistical analyses were performed using the SPSS software, version 15.0 .

\section{Results}

\section{Mucociliary transport}

The mucociliary transport capability exhibited by the fish from the polluted pond $(0.3 \pm 0.1)$ was significantly lower $(p<0.05)$ than that observed in fish from the control site $(1.01 \pm 0.1$; Table 2$)$.

\section{Water}

Water temperatures and $\mathrm{pH}$ levels were similar at both sites. However, conductivity, and ammonia concentrations, and water hardness presented high values in the polluted pond. In addition, dissolved oxygen was also lower in the waters form artificial pond. The physicochemical variables of the water are presented in Table 1.

\section{Hematology and cyto-genotoxicity}

When the hematological parameters of the fish from both sites were compared, the fish from the polluted pond presented significantly higher quantities of monocytes and eosinophils and significantly lower numbers of lymphocytes and neutrophils $(p<0.05)$. Leukocytes and nuclear abnormalities were more frequent in fish from the polluted pond. Meanwhile, the number of erythroblasts was significantly lower in fish from the polluted pond. Basophil frequency did not differ significantly between the groups. Rates of micronuclei were similar between the fish from the two sites, but nuclear abnormalities were significantly more frequent in fish from the polluted pond. The results are compiled in Table 2 .

\section{Discussion}

This study revealed associations between water quality, hematological changes, nuclear abnormalities, and mucociliary transport. The mucociliary transport capabilities exhibited by fish from the polluted pond were significantly lower than those of the controls. Mucus analysis is a promising tool for biomonitoring, because secretion plays a critical role in animal defense. It serves as a natural, semipermeable, chemical, and biological barrier with immunological functions. In fish populations, a link has long been demonstrated between environmental pollution and disease due to the impairment of the innate immune system (Arkoosh et al. 2000; Guardiola et al. 2015; Seriani et al., 2015a; Guardiola et al., 2016).

Changes in fish mucus have been reported by Beamish (1972), Zieske and Bernstein (1982), and Northcott and Beveridge (1988). Lichtenfels et al. (1996) reported that the viscosity of fish mucus may increase the production of acidic glycoprotein (acid mucus), thus enhancing particle retention. Our results are consistent with these studies and suggest that low transportability and high density in vitro is a response of mucus acidification and an effect of the pollutants observed (Lemos et al. 1994; Pires-Neto et al. 2006; Yoshizaki et al. 2010; Seriani et al. 2015c; 2015d; Yoshizaki et al. 2017).

The data also showed that the fish from the polluted pond may be not healthy, since they presented increased numbers of monocytes, eosinophils, total leukocytes, and nuclear abnormalities, lower numbers of lymphocytes, neutrophils, erythroblasts, and thrombocytes, and a lower relative speed of mucociliary transport.

Changes in hematological parameters have been reported in fish exposed both to mixtures of pollutants and to single substances (Bacchett et al. 2011; Seriani et al. 2013; Fujimoto et al. 2012; Carraschi et al. 2016; Cruz et al. 2015; Thummabancha et al. 2016; Kumar et al. 2017). Low frequencies of erythroblasts and thrombocytes could be explained by water contaminants generating intrasplenic and intrahepatic 
Table 1 Physicochemical variables of water samples collected from the polluted urban pond and the control site

\begin{tabular}{llcl}
\hline Variable & Control & Polluted pond & $\begin{array}{l}\text { Brazilian guidelines } \\
\text { CONAMA 357/2005 }\end{array}$ \\
\hline Temperature $\left({ }^{\circ} \mathrm{C}\right)$ & $24 \pm 0.1$ & $24 \pm 0.2$ & - \\
Dissolved oxygen $(\mathrm{mg} / \mathrm{L})$ & $7.4 \pm 0.1$ & $6.1 \pm 0.7$ & $>6$ \\
$\mathrm{pH}$ & $7.0 \pm 0.3$ & $7.1 \pm 0.6$ & $6-9$ \\
Hardness $\left(\mathrm{CaCO}_{3}\right)$ & $54.3 \pm 2.5$ & $130.1 \pm 10$ & - \\
Conductivity $(\mu \mathrm{S} / \mathrm{cm})$ & $227.1 \pm 20.2$ & $420.1 \pm 20$ & - \\
Total ammonia $(\mathrm{mg} / \mathrm{L})$ & $<0.1$ & $3.5 \pm 1.1$ & 3.7 \\
Unionized ammonia $(\mathrm{mg} / \mathrm{L})$ & $<0.01$ & $0.5 \pm 0.2$ & - \\
\hline
\end{tabular}

damage, thus decreasing hematopoiesis. Çavaş (2008) and Corredor-Santamaría et al. (2016) described erythrocyte abnormalities that resulted from the presence of high levels of ammonia and toxic metals. Moreover, Jeney et al. (1992) showed that ammonia could reduce numbered blood cell counts and distorted red blood cell shapes. The experimental fish in this study exhibited lower erythroblast counts.

Leukocytes exhibit high phagocytic activity, and thrombocytes are involved in both blood clotting and the organism's defense system (Passantino et al. 2005). Fish from the polluted urban pond exhibited a higher frequency of total leukocytes, a result previously observed by other authors in studies on fish exposed to contaminants (Zutshi et al. 2010; Gupta et al. 2013; Seriani et al. 2013). An increased amount of leukocytes suggests the occurrence of an adaptive response to chronic stress induced by xenobiotics or pathogens. Prolonged exposure to higher concentrations of toxicants was found to cause failures in leukocyte production; however, increased leukocyte production could be a protective mechanism against pollutants (Svobodova et al. 1994). Leukocytosis in fish may therefore

Table 2 Biological parameters of $O$. niloticus from control waters and a polluted pond. Speed of mucociliary transport $(\mathrm{mm} / \mathrm{min})$, frequency of total leukocytes, thrombocytes, micronuclei, nuclear abnormalities, erythroblasts, and percentage of lymphocytes, neutrophils, basophils, monocytes, and eosinophils. Asterisks show significant difference $(p<0.05)$ between groups

\begin{tabular}{lcc}
\hline Parameters & Control & Polluted pond \\
\hline Speed of mucociliary transport (mm/min) & $1.0 \pm 0.1$ & $0.4 \pm 0.1 *$ \\
LC (\%o) & $11.1 \pm 4.8$ & $26.4 \pm 6.4 *$ \\
TC (\%o) & $32.3 \pm 11.9$ & $10.9 \pm 5.9 *$ \\
Micronuclei (\%o) & $0.6 \pm 0.4$ & $0.8 \pm 0.5$ \\
Nuclear aAbnormalities (\%o) & $9.3 \pm 0.5$ & $17.5 \pm 4.8 *$ \\
Erythroblasts (\%o) & $20.0 \pm 3.2$ & $12.1 \pm 5.7 *$ \\
Lymphocytes (\%) & $91.7 \pm 5.8$ & $86.1 \pm 2.4 *$ \\
Neutrophils (\%) & $9.2 \pm 3.7$ & $6.9 \pm 1.7$ \\
Basophils (\%) & $0.4 \pm 0.6$ & $0.5 \pm 0.6 *$ \\
Monocytes (\%) & $4.0 \pm 2.3$ & $7.3 \pm 1.7 *$ \\
Eosinophils (\%) & $0.3 \pm 0.6$ & $2.0 \pm 0.6 *$ \\
\hline
\end{tabular}

be the consequence of the direct stimulation of their immunological defense systems.

According to Rowley (1988), monocytes normally occur in low numbers in differential white blood cell counts, but they are actively phagocytic cells in piscine fish. They are also involved in the removal of cellular debris from necrotized tissues as part of inflammatory response and other degenerative processes, so much so that monocytosis could be suggestive of an inflammatory response in teleost fish. These blood cells, considered to be the most important in the immune system (Clauss et al. 2008), could migrate to sites that may have been damaged as a result of toxic effects (such as apoptosis or tissue damage). Therefore, if leukopoietic centers were lesioned, as observed previously by Lemly (2002) and by Sorensen et al. (1982), (Sorensen and Bauer 1984), the release of these cells would be inhibited or even impeded. Thus, the presence of these cells in the present study is a clear indicator of internal lesions in fish from the polluted pond.

Some reports indicate that eosinophils are also involved in inflammatory responses, despite their limited phagocytic capability (Rowley 1988). Rothenberg and Hogan (2006) showed that eosinophils are pleiotropic multifunctional leukocytes involved in the initiation and propagation of diverse inflammatory responses, as well as modulators of innate and adaptive immunity. This cell type is rarely observed in the blood of fish, and the high number of eosinophils in fish from the polluted site was surprising: these results suggest that the increase in this type of cell may be associated with inflammatory processes due to either parasite infestation or chemical compounds present in effluents (Corrêa et al. 2017).

On the other hand, there were lower counts of some cell types, including lymphocytes and neutrophils. The frequency of the thrombocytes was also lower. According to Sorensen (1991), lower neutrophils counts may indicate a disruption of phagocytic capacity and, consequently, a reduction in the fish's resistance to pathogens. Lymphocyte frequency has been associated with resistance to disease. Nicholson et al. (1990) reported that, at low to moderate levels of stress, this kind of reduction may be not caused by direct suppression of 
antibody production. Thus, reduced lymphocyte counts in fish from the polluted pond considered herein were due to lymphocytopoiesis and not to mechanisms involving cortisol.

The thrombocytopenia observed in our study could have devastating effects on fish, because these cells are responsible not only for blood clotting, but also for controlling fluid loss from surface wounds in fish (Clauss et al. 2008). The decrease in the number of these cells in peripheral blood may suggest migration to hemorrhagic foci, as observed by Mazon et al. (2002) and Pereira et al. (2013) in studies on the genus Prochilodus.

Cyto-genotoxicity biomarkers, such as frequency of nuclear abnormalities and micronuclei, were measured, but only nuclear abnormalities appeared to be significantly higher in fish from the polluted pond. Measurements of nuclear abnormalities seemed to be more sensitive than those of micronuclei. These results suggest the occurrence of genotoxicity in $O$. niloticus specimens (Kirschbaum et al. 2009; Çavas and Ergene-Gözükara 2005). Similar effects have been reported in studies on fish collected from other polluted sites. García-Medina et al. (2011) investigated fish collected from sites along the Ocoa River receiving untreated domestic sewage and observed an increased incidence of binucleate erythrocytes; the authors attributed the genotoxic effects to the pollutants found in the river waters. In our study, nuclear abnormalities were found to be more frequent than micronuclei.

The water from the polluted pond seemed to exhibit some evidence of changes in quality, since conductivity and hardness were higher than those of the control site. Ammonia levels were higher in the polluted pond but were still below the limits established by the National Environmental Council of Brazil (CONAMA 2005) and the São Paulo State Sanitation Technology Company (CETESB 2009). On the other hand, electric conductivity data provide information on ion concentrations and aid in the detection of pollutant sources in aquatic ecosystems (Esteves 2011). Conductivity and ion concentrations in particular indicate changes in the chemical composition of the water; however, these data do not provide any indication of the specific concentrations of each ion (CETESB 2009). Moreover, Esteves (2011) also stated that the water hardness may be influenced by rainfall regime, geological characteristics of the catchment or basin, and inputs of anthropic origin. In this sense, despite the lack of legal standards for hardness and conductivity in Brazilian waters, the higher values found in the polluted pond may represent degradation resulting from the proximity of residential areas. It is also important to note that this body of water receives domestic effluent discharge, urban drainage, and storm waters, and that water renewal is very low and depends exclusively on rainfall rates.

Hardness is associated with concentrations of calcium and magnesium (carbonates and bicarbonates), which can modify the solubility of some metals or the behavior of organic compounds in the aqueous medium. Hardness has been found to be associated with increases in metal toxicity in studies on rainbow trout (Sinley et al. 1974), Poecilia reticulata (Gianotti 1986), and Clarias gariepinus (Molokwu and Okpokwasili 2002), whereas other studies have found that the increase in water hardness lowers metal toxicity (Javid et al. 2007; Kim et al. 2001; Pyle et al. 2002).

Conductivity represents the number of suspended particles in the water, particles which may be anything from organic matter to microbeads and other pollutants. The ideal value of conductivity for fish health lies between 20 and $100 \mu \mathrm{S} / \mathrm{cm}$ (Zimmermann et al. 2001). Moreover, conductivity provides important data about aquatic metabolism and helps to identify the presence of pollutants: high values could be indicative of elevated levels of decomposition, and lower values may point to primary productivity. According to Felipe and Súarez (2010), high values of hardness increase the abundance of species tolerant to losses of water quality.

Changes in ammonia, hardness, and conductivity levels have been frequently associated with the input of sewage and/or urban storm water runoff, sources which are considered complex mixtures containing many toxic compounds, such as organic substances, pharmaceuticals, personal care products, metals, hydrocarbons, detergents, pesticides, drugs, and other toxics (Sibanda et al. 2015; Pereira et al. 2016; Silva et al. 2017).

In conclusion, the fish from the polluted pond exhibited several signs of effects on blood cell composition, as well as more frequent nuclear abnormalities and changes to mucus transportability. These findings suggest that the polluted pond's waters are not suitable for the aquatic organisms. The biomarkers used in this study can be considered good indicators of pond water quality, and they are advantageous as tools because they do not require euthanasia. The causes of the increase in leukocyte (monocyte and eosinophil) quantities remain unclear and require further investigation.

Acknowledgments The authors would like to thank Dr. Rogerio Pazzeti for providing the frog palate and Dr. Mariângela Macchione for her help during frog palate preparation sampling. The authors are also grateful to Mrs. Sonia A.S. Feliciano and Mr. Guilherme F. Cavalheiro for their assistance in laboratorial procedures and to vivarium technicians $\mathrm{Mr}$. Luiz Afonso, Mr. Davi Francisco, and Mr. Ivandir. D.M.S. Abessa thanks the Brazilian National Council for Scientific and Technological Development $(\mathrm{CNPq})$ for the financial support. The authors would also like to thank Danielle Deremo Cosimo of Superior Translation Services for reviewing the manuscript.

\section{Compliance with ethical standards}

Conflict of interest The authors declare that they have no conflict of interest. 


\section{References}

APHA (American Public Health Association) (2005) AWWA American Water Works Association WPCF-Water Pollution Control Federation, 21st edn. Standard Methods for the Examination of Water and Wastewater, Washington, DC

Araújo ALS, Guimarães ET, Seriani R (2014) Mutagenesis in Tradescantia pallida as a biomarker of the effects of water polluted with urban effluent. Holos Environ 14(1):97-102. 10.14295/holos. v14i1.6911

Arkoosh M, Casillas E, Clemons E, Huffman P, Kagley A, Collier T, Stein J (2000) Increased susceptibility of juvenile chinook salmon to infectious disease after exposure to chlorinated and aromatic compounds found in contaminated urban estuaries. Mar Environ Res 50(1):470-471. https://doi.org/10.1016/S0141-1136(00)00225-7

Bacchett C, Cazenave J, Parma MJ (2011) Responses of biochemical markers in the fish Prochilodus lineatus exposed to a commercial formulation of endosulfan. Water Air Soil Pollut 216(1-4):39-49. https://doi.org/10.1007/s11270-010-0512-z

Beamish RJ (1972) Lethal pH for the white sucker Catostomus commersoni (Lacepede). Trans Am Fish Soc 101(2):355-358. https://doi.org/10.1577/1548-8659(1972)101<355:LPFTWS>2.0. $\mathrm{CO} ; 2$

Bonnail E, Buruaem LM, Araujo GS, Abessa DM, Del Valls TA (2016) Multiple biomarker responses in Corbicula fluminea exposed to copper in laboratory toxicity tests. Arch Environ Contam Toxicol 2(71):278-285

Bucker A, Carvalho M, Conceição M, Alves-Gomes J (2012) Micronucleus test and comet assay in erythrocytes of the Amazonian electric fish Apteronotus bonapartii exposed to benzene. Ecotoxicol Environ Cont 7(1):65-73

Carraschi SP, Florêncio T, Ignácio NF, Ikefuti CV, Cruz C, Ranzani-Paiva MJT (2016) Hematological and histopathological assessment of pacu (Piaractus mesopotamicus) after treatment of pathogens with veterinary medicinal products. Comp Clin Path 1(26):105-114

Çavaş T (2008) In vivo genotoxicity of mercury chloride and lead acetate: micronucleus test on acridine orange stained fish cells. Food and Chem Toxicology 46(1):352-358

Çavas T, Ergene-Gözükara S (2005) Micronucleus test in fish cells: a bioassay for in situ monitoring of genotoxic pollution in the marine environment. Environ Mol Mut 46(1):64-70. https://doi.org/10. 1002/em.20130

CETESB (Companhia Ambiental do Estado de São Paulo) (2009) Qualidade das águas interiores no Estado De São Paulo. Significado ambiental e sanitário das variáveis de qualidade das águas e dos sedimentos e metodologias analíticas e de amostragem. Serie Relatorios Apendice A. In: http://www.cetesb.sp.gov.br/

Clauss TM, Dove ADM, Arnold JE (2008) Hematologic disorder of fish. Vet Clin North Am Exot Anim Pract 11(3):445-462. https://doi.org/ 10.1016/j.cvex.2008.03.007

CONAMA (Conselho Nacional do Meio Ambiente) (2005) Dispõe sobre a classificação dos corpos de água e diretrizes ambientais para o seu enquadramento, bem como estabelece as condições e padrões de lançamento de efluentes, e da outras providencias. In: http://www. mma.gov.br/port/conama/legiabre.cfm?codlegi $=459$

Corrêa SADS, Abessa DMDS, Santos LGD, Silva EB, Seriani R (2017) Differential blood counting in fish as a non-destructive biomarker of water contamination exposure. Toxicol Environ Chem 99(3):482491

Corredor-Santamaría W, Gómez MS, Velasco-Santamaría YM (2016) Using genotoxic and haematological biomarkers as an evidence of environmental contamination in the Ocoa River native fish, Villavicencio-Meta, Colombia. SpringerPlus 5(1):351. https:// doi.org/10.1186/s40064-016-1753-0
Cruz AL, Prado TM, Maciel LAS, Couto RD (2015) Environmental effects on the gills and blood of Oreochromis niloticus exposed to rivers of Bahia, Brazil. Ecotoxicol Environ Saf 111:23-31. https:// doi.org/10.1016/j.ecoenv.2014.09.022

Delbon MCE, Paiva MJTR (2012) Eugenol em juvenis de tilápia do Nilo: concentrações e administrações sucessivas. Bol Inst Pesca 38(1):4352

Duarte LFA, Souza CA, Nobre CR, Pereira CDS, Pinheiro MAA (2016) Multi-level biological responses in Ucides cordatus (Linnaeus, 1763) (Brachyura, Ucididae) as indicators of conservation status in mangrove areas from the western atlantic. Ecotoxicol Environ Saf 133:176-187. https://doi.org/10.1016/j.ecoenv.2016.07.018

Esteves FDA (2011) Fundamentos de limnologia, 3rd edn. Editora Interciência, Rio de Janeiro

Felipe TRA, Súarez YR (2010) Caracterização e influência dos fatores ambientais nas assembleias de peixes de riachos em duas microbacias urbanas, Alto Rio Paraná. Biota Neotrop 10(2):144 151

Flores-Ramírez R, Pérez-Vázquez FJ, Rodríguez-Aguilar M, MedellínGaribay SE, Brussel E, Cubillas-Tejeda AC, Díaz-Barriga F (2017) Biomonitoring of persistent organic pollutants (POPs) in child populations living near contaminated sites in Mexico. Sci Total Environ 579:1120-1126. https://doi.org/10.1016/j.scitotenv.2016.11.087

Fujimoto RY, Costa HC, Ramos FM (2012) Controle alternativo de helmintos de Astyanax cf. zonatus utilizando fitoterapia com sementes de abóbora (Cucurbita maxima) e mamão (Carica papaya). Pesq Vet Bras 32(1):5-10. https://doi.org/10.1590/S0100736X2012000100002

García-Medina S, Razo-Estrada C, Galar-Martinez M, Cortéz-Barberena E, Manuel Gómez-Oliván LM, Álvarez-González I, MadrigalBujaidar E (2011) Genotoxic and cytotoxic effects induced by aluminum in the lymphocytes of the common carp (Cyprinus carpio). Comp Biochem Physiol Part C Toxicol Pharmacol 153(1):113-118. https://doi.org/10.1016/j.cbpc.2010.09.005

Gianotti EP (1986) Contaminaçäo das águas pelo zinco: a dureza da água como um fator de modificaçäo da toxicidade do zinco a peixes. Rev DAE 46(145): 187-193

Guardiola FA, Dioguardi M, Parisi MG, Trapani MR, Meseguer J, Cuesta A, Esteban MA (2015) Evaluation of waterborne exposure to heavy metals in innate immune defences present on skin mucus of gilthead seabream (Sparus aurata). Fish Shellfish Immunol 45(1):112-123. https://doi.org/10.1016/j.fsi.2015.02.010

Guardiola FA, Cuesta A, Esteban MA (2016) Using skin mucus to evaluate stress in gilthead seabream (Sparus aurata L.) Fish Shellfish Immunol 59:323-330. https://doi.org/10.1016/j.fsi.2016.11.005

Gupta SK, Pal AK, Sahu NP, Jha AK, Akhtar MS, Mandal SC, Prusty AK (2013) Supplementation of microbial levan in the diet of Cyprinus carpio fry (Linnaeus, 1758) exposed to sublethal toxicity of fipronil: effect on growth and metabolic responses. Fish Physiol Biochem 39(6):1513-1524. https://doi.org/10.1007/s10695-013-9805-7

Hedayati A, Darabitabar F (2017) Lethal and sub-lethal impacts of lead on some hematological, biochemical and immunological indices in Caspian roach (Rutilus rutilus). Pollution 3(1):21-27

Javid A, Javed M, Abdullah S (2007) Nickel bio-accumulation in the bodies of Catla catla, Labeo rohita and Cirrhina mrigala during 96-hr LC50 exposures. Int J Agric Biol 9:139-142

Jeney G, Nemcsok J, Jeney ZS, Olah J (1992) Acute effect of sublethal ammonia concentrations on common carp (Cyprinus carpio L.). II effect of ammonia on blood plasma transminases (GOT, GPT), G1DH enzyme activity, and ATP value. Aquaculture 104(1-2): 149-156. https://doi.org/10.1016/0044-8486(92)90145-B

Kim AD, Gu MB, Allen HE, Cha D (2001) Physiochemical factors affecting the sensitivity of Ceriodaphnia bulba to copper. Environ Monit Assess 70(1/2):105-116. https://doi.org/10.1023/A: 1010689432130 
King M (1986) The role of mucus viscoelasticity in cough clearance. Biorheology 24:589-597

Kirschbaum AA, Seriani R, Pereira CD, Assunção A, Abessa DM, Rotundo MM, Ranzani-Paiva MJ (2009) Cytogenotoxicity biomarkers in fat snook Centropomus parallelus from Cananéia and São Vicente estuaries, SP, Brazil. Gen. Mol Biol 32(1):151-154

Koreleff F (1970) Direct determination of ammonia in natural waters as indophenol blue. Information on techniques and methods for seawater analysis. ICES Interlaboratory Rep 3:19-22

Kumar M, Kumar D, Kumar R (2017) Sublethal effects of cadmium and copper on the blood characteristics of catfish Clarias batrachus (Linn.) Int J Adv Res Biol Sci 4(1):123-128. https://doi.org/10. 22192/ijarbs.2017.04.01.013

Lemly AD (2002) Symptoms and implications of selenium toxicity in fish: the belews lake case example. Aquat Toxicol 57(1):39-49

Lemos M, Lichtenfels AJFC, Amaro E, Macchione M, Martins MA, King M, Bohm GM, Saldiva PHN (1994) Quantitative pathology of nasal passages in rats exposed to urban levels of air pollution. Environ Res 66(1):87-95. https://doi.org/10.1006/enrs.1994.1046

Lichtenfels AJFC, Lorenzi-Filho G, Guimaraes ET, Macchione M, Saldiva PHN (1996) Effects of water pollution on the gill apparatus of fish. J Comp Pathol 115(1):47-60. https://doi.org/10.1016/ S0021-9975(96)80027-2

Macchione M, King M, Lorenzi-Filho G, Guimaraes ET, Zin WA, Böhm GM, Saldiva PHN (1995) Rheological determinants of mucociliary transport in the nose of the rat. Resp Physiol 99(1):165-172. https:// doi.org/10.1016/0034-5687(94)00080-J

Mazon AF, Monteiro EAS, Pinheiro GHD, Fernandes MN (2002) Hematological and physiological changes induced by short-term exposure to copper in the freshwater fish Prochilodus scrofa. Braz J Biol 62(4A):621-663. https://doi.org/10.1590/S151969842002000400010

Molokwu CN, Okpokwasili GC (2002) Effect of water hardness on egg hatchability and larval viability of Clarias gariepinus. Aquacult Int 10(1):57-64. https://doi.org/10.1023/A:1021395122919

Morris JT, Barber DC, Callaway JC, Chambers R, Hagen SC, Hopkinson CS, Wigand C (2016) Contributions of organic and inorganic matter to sediment volume and accretion in tidal wetlands at steady state. Earth's Future 4(4):110-121. https://doi.org/10.1002/ 2015EF000334

Nicholson LC, Woods LC, Woiwode JG (1990) Intensive culture techniques for the striped bass and its hybrids. In: Harrell RM, Kerby JH, Minton RV (eds) Culture and propagation of striped bass and its hybrids. American Fisheries Society, Bethesda, pp 141-158

Northcott ME, Beveridge MCM (1988) The development and structure of pharyngeal apparatus associated with filter feeding in tilapias (Oreochromis niloticus). J Zool 215(1):133-149. https://doi.org/ 10.1111/j.1469-7998.1988.tb04889.x

Passantino L, Cianciotta A, Patruno R, Ribaud MR, Jirillo E, Assantino GF (2005) Do fish thombocytes play an immunological role? Their cytoenzimatic profiles and fuction during an accidental piscine candidiasis in aquarium. Immunopharmcol Immunotoxicol New York 7:345-356

Pereira L, Fernandes MN, Martinez CB (2013) Hematological and biochemical alterations in the fish Prochilodus lineatus caused by the herbicide clomazone. Environ Toxicol Pharmacol 36(1):1-8. https:// doi.org/10.1016/j.etap.2013.02.019

Pereira CDS, Maranho LA, Cortez FS, Pusceddu FH, Santos AR, Ribeiro DA, Guimarães LL (2016) Occurrence of pharmaceuticals and cocaine in a Brazilian coastal zone. Sci Total Environ 548:148-154

Pires-Neto RC, Lichtenfels AJ, Regina Soares S, Macchione M, Saldiva PHN, Dolhnikoff M (2006) Effects of São Paulo air pollution on the upper airways of mice. Environ Res 101(3):356-361. https://doi. org/10.1016/j.envres.2005.12.018

Prado LR, Felix C, Abessa DM, Buruaem LM, Abujamara LD, Kirschbaum AA, Turatti GCR, Ranzani-Paiva MJT, Correia AT,
Seriani R (2014) Hematological parameters and nuclear abnormalities in peripheral erythrocytes of Achirus lineatus (Pleuronectiformes: Achiridae). Comp Clin Pathol 361:1-7

Pyle GG, Swanson SM, Lehmkuht DM (2002) The influence of water hardness, $\mathrm{pH}$, and suspended solids on nickel toxicity to larva fathead minnows (Pimephales promelas). Water Air Soil Poll 133(1/4): 215-226. https://doi.org/10.1023/A:1012973728628

Rosenfeld G (1947) Corante pancrômico para a hematologia e citologia clínica: nova combinação dos componentes do May-Grünwald e do Giemsa num só corante de emprego rápido. Memórias do Instituto Butantan 20(1):329-334

Rothenberg ME, Hogan SP (2006) The eosinophil. An. Rev Immunol 4: $147-174$

Rowley AF (1988) In: Rowley AF, Ratcliffe N (eds) Vertebrate blood cells. Cambridge, Cambridge University, pp 119-127

Sadauskas-Henrique H, Duarte RM, Gagnon MM, Almeida-Val VMF (2017) Validation of a suite of biomarkers of fish health in the tropical bioindicator species, tambaqui (Colossoma macropomum). Ecol Indic 73:443-451. https://doi.org/10.1016/j.ecolind.2016.10.010

Saldiva PHN (1990) Aparelho mucociliar: aspectos funcionais e métodos de estudo. J Pneumol 16(3):161-170

Seriani R, Ranzani-Paiva MJT, Silva-Souza AT, Napoleão SR (2011) Hematology, micronuclei and nuclear abnormalities in fishes from São Francisco river, Minas Gerais state, Brazil. Acta Scient Biol Sci 33(1):107-112

Seriani R, Abessa DMS, Kirschbaum AA, Pereira CDS, Ranzani-Paiva MJT, Assunção A, Silveira FL, Romano P, Mucci JLN (2012a) Water toxicity and cyto-genotoxicity biomarkers in the fish Oreochromis niloticus (Cichlidae). J Braz Soc Ecotoxicol 7(2):6772. https://doi.org/10.5132/jbse.2012.02.010

Seriani R, Abessa DMS, Kirschbaum AA, Pereira CDS, Romano P, Ranzani-Paiva MJT (2012b) Relationship between water toxicity and hematological changes in Oreochromis niloticus. Braz J Aquat Sci Technol 15(2):47-53

Seriani R, Abessa DMS, Pereira CD, Kirschbaum AA, Assunção A, Ranzani-Paiva MJT (2013) Influence of seasonality and pollution on the hematological parameters of the estuarine fish Centropomus parallelus. Braz J Ocean 61(2):105-111. https://doi.org/10.1590/ S1679-87592013000200003

Seriani R, Abessa DMS, Moreira LB, Cabrera JP, Sanches JQ, Silva CL, Amorim FA, Rivero DHRF, Silva FL, Fitorra LS, Carvalho-Oliveira R, Macchione M, Ranzani-Paiva MJT (2015a) In vitro mucus transportability, cytogenotoxicity, and hematological changes as nondestructive physiological biomarkers in fish chronically exposed to metals. Ecotoxicol Environ Saf 112:162-168. https://doi.org/10. 1016/j.ecoenv.2014.11.003

Seriani R, Junqueira MS, Toledo AC, Corrêa AT, Silva LF, Martins MA, Saldiva PHS, Macchione M (2015b) Organic and inorganic fractions of diesel exhaust particles produce changes in mucin profile of mouse trachea explants. J Toxicol Environ Health Part A 78(4):215-225. https://doi.org/10.1080/15287394.2014. 947456

Seriani R, Junqueira MDS, Toledo AC, Martins MA, Seckler M, Alencar AM, Negri EM, Silva LFF, Maud T, Saldiva PHS, Macchione M (2015c) Diesel exhaust particulates affect cell signaling, mucin profiles, and apoptosis in trachea explants of Balb/C mice. Environ Toxicol 30(11):1297-1308. https://doi.org/10.1002/tox.22000

Seriani R, Junqueira MS, Toledo AC, Corrêa AT, Silva LF, Martins MA, Macchione M (2015d) Organic and inorganic fractions of diesel exhaust particles produce changes in mucin profile of mouse trachea explants. Health, Part A. J Toxicol Environ 78(4):215-225

Sibanda T, Selvarajan R, Tekere M (2015) Urban effluent discharges as causes of public and environmental health concerns in South Africa's aquatic milieu. Environ Sci Poll Res Int 22(23):1830118317. https://doi.org/10.1007/s11356-015-5416-4 
Silva AM, Abessa D, Pamplin PAZ, Bohrer-Morel MB (2017) Ecological risk assessment of a subtropical river influenced by discharges of residues from water and sewage treatment plants. Man Environ Quality An Int J 28(2):156-174

Simões LN, Gomide ATM, Almeida-Val VMF, Val AL, Gomes LC (2012) O uso do óleo de cravo como anestésico em juvenis avançados de tilápia do Nilo (Oreochromis niloticus). Acta Sci Anim Sci 34(2):175-181

Sinley JR, Goettl JP, Davies PH (1974) The effects of zinc on rainbow trout (Salmo gairdneri) in hard and soft water. Bull Environ Cont Toxicol 12(2):193-201. https://doi.org/10.1007/BF01684960

Sorensen EMB (1991) Metal poising in fish. CRC Press, Boca Ranton

Sorensen EM, Bauer TL (1984) A correlation between selenium accumulation in sunfish and changes in condition factor and organ weight. Environ Pollut A Ecol Biol 34(4):357-366. https://doi.org/10.1016/ 0143-1471(84)90113-2

Sorensen EMB, Harlan CW, Bell JS (1982) Renal changes in seleniumexposed fish. Am J Forensic Med Path 3(2):123-129. https://doi. org/10.1097/00000433-198206000-00007

Svobodova Z, Vykusova B, Machova J (1994) The effects of pollutants on selected haematological and biochemical parameters in fish. In: Muller R, Lloyd R (eds) Sublethal and chronic effects of pollutants on freshwater fish. FAO Fishing News Nooks, Oxford, pp 39-52

Thomé RG, Silva PM, Santos HB (2016) Avaliação de genotoxidade da água de um rio urbano utilizando estudo de células sanguíneas de Danio rerio. Conexão Ciência (Online) 11(2):9-16

Thummabancha K, Onparn N, Srisapoome P (2016) Analysis of hematologic alterations, immune responses and metallothionein gene expression in Nile tilapia (Oreochromis niloticus) exposed to silver nanoparticles. J Immunotoxicol 13(6):909-917. https://doi.org/10. 1080/1547691X.2016.1242673

Trindade SHK, Seriani R, Lorenzi-Filho G, Ferreira de Mello Júnior J, Sennes LU, Saldiva PHN, Macchione M (2018) Effects of organic and inorganic compounds of diesel exhaust particles on the mucociliary epithelium: An experimental study on the frog palate preparation. Ecotoxicology and Environmental Safety 148:608614. https://doi.org/10.1016/j.ecoenv.2017.10.041

Vieira CED, Costa PG, Cabrera LC, Primel EG, Fillmann G, Bianchini A, Martinez CBR (2017) A comparative approach using biomarkers in feral and caged Neotropical fish: implications for biomonitoring freshwater ecosystems in agricultural areas. Sci Total Environ 586: 598-609. https://doi.org/10.1016/j.scitotenv.2017.02.026

Weldetinsae A, Dawit M, Getahun A, Patil HS, Alemayehu E, Gizaw M, Abera D (2017) Aneugenicity and clastogenicity in freshwater fish Oreochromis niloticus exposed to incipient safe concentration of tannery effluent. Ecotoxicol Environ Saf 138:98-104. https://doi. org/10.1016/j.ecoenv.2016.10.026

Yoshizaki K, Brito JM, Toledo AC, Nakagawa NK, Piccin VS, Junqueira MS, Negri EM, Carvalho ALN, Ligeiro de Oliveira AP, Tavares de Lima W, Saldiva PHN, Mauad T, Macchione M (2010) Subchronic effects of nasally instilled diesel exhaust particulates on the nasal and airway epithelia in mice. Inhal Toxicol 22(7):610-617. https:// doi.org/10.3109/08958371003621633

Yoshizaki K, Brito JM, Silva LF, Lino-dos-Santos-Franco A, Frias DP, Silva RCR, Macchione M (2017) The effects of particulate matter on inflammation of respiratory system: differences between male and female. Sci Total Environ 586:284-295. https://doi.org/10.1016/j. scitotenv.2017.01.221

Zieske JD, Bernstein IA (1982) Modification of cell surface glycoprotein: addition of fucosyl residues during epidermal differentiation. J Cell Biol 95(2):626-631

Zimmermann S, Moreira HLM, Vargas L, Ribeiro RP (2001) Fundamentos da moderna aquicultura. ULBRA, Canoas

Zutshi B, Prasad SGR, Nagaraja R (2010) Alteration in hematology of Labeo rohita under stress of pollution from Lakes of Bangalore, Karnataka, India. Environ Monit Assess 168(1): 11-1, 19, DOI: https://doi.org/10.1007/s10661-009-1087-2 